\title{
Technology Enhanced Learning in Teaching Foundation Skills for Literacy and Numeracy among Vulnerable Children in the North Eastern Parts of Adamawa State
}

\author{
Bitrus Ishaya, Ezekiel K. Etienne
}

\begin{abstract}
The term Technology-enhanced learning (TEL) is concerned with using technologies to support learning whether in school, workplace or at home through the use of instructional materials like smart boards, projectors, educational Ipad/tablets etc. This research is an attempt to find out the impact of how TEL is deployed in teaching the vulnerable children in boko haram ravaged communities in the north east. The survey method was used in conducting the research and the data consists of some purposively selected schools in the north east to identify the truth or otherwise in the deployment of TEL in teaching the vulnerable children. The study also exposes the complexity arising from systemic alienation, disempowerment and hardship facing the IDPs and public schools in Northeastern Nigeria culminating into the dynamic effects on the educational deprivation of the Nigerian children. Based on the findings, recommendations were proffered and prominent among them include the need for Government as a matter of urgency provide appropriate equipment and materials needed for effective TEL programs in all the Federating units. Both federal and state ministries of education, human resources and agencies interested in children education should be made to initiate programs aimed at promoting TEL activities in all schools.
\end{abstract}

Index Terms - alienation, deploy, deprivation, purposive, ravage, smart-boards, systemic, technology-enhanced, vulnerable.

\section{INTRODUCTION}

Humanitarian crisis generally has changed our worldview because there is a deep desire to improve the lives of both the Internally Displaced Persons (IDPs) living with us, as well as the local people living in poverty. It is reported by African Union Convention for the Protection and Assistance of Internally Displaced Persons in Africa, (Kampala Convention 2009) to be one of the major causes of the rise in school drops and by extension illiteracy in general. Numerous strategies by governments and aid agencies are being deployed towards reducing the trend in illiteracy.

With United States Agency for International Development (USAID) funding, American University of Nigeria (AUN) is implementing an education project to teach over 22,000 vulnerable children in the local community on basic literacy and numeracy skills, using technology

Bitrus Ishaya, Department of English Language Education Adamawa State Polytechnic, Yola Adamawa State, Nigeria

Ezekiel K. Etienne, Department of International Relations and Strategic Studies, Adamawa State Polytechnic, Yola, Adamawa State, Nigeria enhanced techniques developed by computer science students and radio programs written and produced by multimedia students of the University.

Technology-enhanced learning (TEL) research focuses on how technologies can add value to learning and teaching processes. Today's learners have access to increasingly powerful and affordable handheld computing devices, including smart phones, games, consoles and tablets. They can share, interact and immerse themselves online with others through the use of social networks and virtual worlds. They can also create identities and user-generated resources that potentially have a virtual worldwide audience enabled by the Internet. Learners' activities can be captured in real time and feedback processes automated with increasing precision through learning analytics.

TEL is able to make use of different forms and formats of technology in the pursuit of more engaging and beneficial forms of teaching, learning, pedagogy and assessment. As this report highlights, good pedagogic intentions lie behind some of this development but, many important (TEL) developments have often come from innovating with technologies developed for other purposes.

Successive programs funded by the European Union (EU) have served to aid the integration of research and the emergence of new research in communities in relation to technology-enhanced learning. These have included the PROLEARN Network of Excellence that dealt with technology-enhanced professional learning (2004-2008) and the Kaleidoscope Network of Excellence focused on technology enhanced learning and access to cultural heritage (2004-2008). These were followed by STELLAR, the European Network of Excellence in TEL (2009-2012). The STELLAR website specified that the network represented 'the effort of the leading institutions and projects in European Technology-Enhanced Learning (TEL) to unify our diverse community'. Each of these networks brought together broad teams of researchers working in diverse fields, including computer-supported collaborative learning (CSCL), blended and informal learning.

Educators have integrated technology into their instructions for as long as there have been classrooms. Whether through textbooks, an overhead projector, a film strip, or an online simulation, teachers have always looked toward technology to provide students with higher quality learning experiences. 
However, innovations in content delivery, assessment methods, and adaptive learning are changing what it means to educate students in the 21 st century. New technologies are enhancing our understanding of how students learn and providing instructors the ability to customize course materials and create personalized learning experiences tailored to students' individual needs.

As technology and instructional methods evolve, so do students' expectations for a technology-driven learning experience.

\section{Theoretical Framework}

The theory used for the explanation of this study is the social exclusion theory. The theory argues that social exclusion subject individuals and groups to discriminatory practices that expose them to humiliations and deprivations. It avers that social exclusion detaches and alienates some groups of individuals from the mainstream of society with resultant negative effects on their citizenship and other socioeconomic rights. These exclusions are not just limited to material resources but also to matters like social participation, culture and education, access to social services and power. The theory is associated with the works of scholars such as

Pacione, (1997) and Hills, (1998) among others. The theory is very apt for the study as it graphically captures the essence and focus of the study. This is because it not only exposes the complexity of the persistent powerlessness arising from systemic deprivations, humiliations disempowerment, alienation and hardship facing the IDPs in the Northeastern Nigeria but their dynamics effects on the socio-economic health of Nigerian state.

\section{Boko Haram and Internal Displacement in Nigeria} Officially, Boko Haram is called Jama'atuAhlis Sunna Lidda'awatiWal-Jihad which in Arabic means "People Committed to the Propagation of the Prophet's Teachings and Jihad" (Liolio, 2013:33). The group which is better known by its Hausa name 'Boko Haram' was a local radical Salafist group which transformed into a Salafi jihadist terrorist organization after 2009. It is based in the North-East of Nigeria, in the areas predominated by the Kanuri people. Loosely translated from the local Hausa language, Boko Haram means, 'Western education or civilization is forbidden.' Put differently, 'Western education or civilization is a sin, (Liolio, 2013).

Since Boko Haram began its campaign of terror against the Nigerian state, several people have been forced to flee their homes for areas safety in the states of Adamawa, Bauchi, Borno, Gombe, Taraba, and Yobe.
IDPs in Northeast as at February, 2015.

\begin{tabular}{|lr|}
\hline $\begin{array}{c}\text { State } \\
\text { Number of IDPs }\end{array}$ & of \\
\hline Adamawa & location \\
Bauchi & 220,159 \\
555 & 60, \\
Borno & 672,714 \\
Gombe & 24, \\
655 & 74,125 \\
Taraba & 135,810 \\
Yobe & \\
& \\
& \\
\hline Grand & total \\
$1,188,018$ & \\
\hline
\end{tabular}

Source: Displacement Tracking Matrix (DTM, 2015)

Relevance of TEL

Technology-Enhanced Learning (TEL) is important for many reasons because it is the standard of education that is expected in this contemporary era as improve education. Children learn at their own pace and sometimes the traditional classroom makes it difficult to do so. Students who need extra time can spend more going over exercises until they understand, whilst students who need less support can continue ahead. It also frees up the teacher to help kids who need more support on an individual level. With TEL, educators are no longer limited to the textbooks that their institutions provide. By using other resources such as video, audio and interactive learning, students have many different ways to learn. Teachers can find creative alternative to teach their students in an engaging way. Technology has changed the learning environment so that learning is more hands-on.

\section{RESUlT AND DisCUSSION}

This section presents the result of the field survey conducted on how TEL is being deployed in the study area, it is no doubt, is a gateway to revolutionizing learning especially at the preschool and elementary levels. Despite the fact that it offers both the teachers and learners new ways of interaction that enhances the attainment of learning outcomes, yet there is a general perception that the associated devices may not be user friendly, unaffordable and thus not sustainable. This perception is rife in less privileged technology states of Africa. Perhaps, it is this numerous host of challenges deemed to be associated with the use of technology in education in terms of those related to cost-effectiveness, teacher professional development, assessment, equity, and safety, that governments in Nigeria are yet to key into the Technology Enhanced Learning mantra.

TEL is all about the adoption and adaption of evidence-based, technology-driven classroom practices and online strategies that enhance learning for all students, especially those at the nursery/primary school levels. Technology enhanced learning involves the application of technology (both analogue and digital) to teaching and learning. Of late is a general shift from analogue to digital TEL, taking over education in the 
form of different types of educational software, toys and related devices. This is more-so because TEL offers the advantage of learners learning at their own pace and individual levels making learning both exciting and interactive and engaging, thus offering the learner an early skill start into the world of technology.

Today's teachers understand the importance of social interaction and one-on-one time to communicate and learn which is what TELs offer. This is for example, in the form of interactive games that can reinforce English vocabularies or math concepts or location of places on the globe and add a fun layer to storytelling when programs are designed specifically with the needs of young children in mind. Examples of TEL tools include:

1. Electronic Whiteboards

2. Flipped Learning

3. Desktops and Laptops

4. Projectors

5. Videoconferencing Classroom Technologies

6. Mobile Learning

7. Television

8. Other new emerging technologies such as ipads, itoys, etc

Take for example the use of a SMART Board, which is an interactive whiteboard that functions as a touch screen, allowing both pupils and teachers to manipulate and move images, words, or graphics on the screen with the touch of a hand. It also allows for projection of video or audio files. Teachers are able to take typical lessons and creative interactive, unique experiences. It offers the flexibility to include different forms of media- photos, illustrations, games and videos.

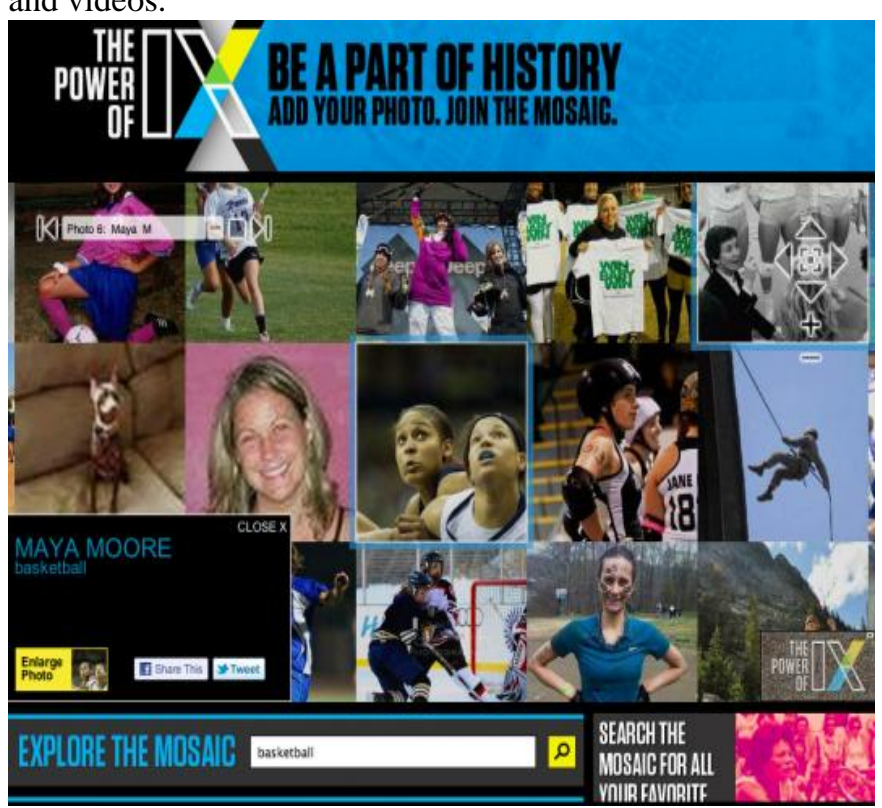

Figure 1: ESPNw's Customer Photo Mosaic

An example of media-photo, games and videos

Another example is the use of a flipped classroom designed to invert traditional teaching methods by enabling mobile teaching after working hours, usually at home when children are able to watch instructional videos at their own pace. During formal class time, children are given activities that help them engage with concepts. Rather than just standing in front of the class and reading from a textbook or tablet, teachers become "guides on the side", available to answer questions and lead discussions. The basic idea is to move learning beyond traditional pen-and-paper "sage on stage model" always using chalk and dry-erase boards to, more recently, the use of smart boards ipads, itoys and other educational devices to enhance learning (Figure 2). Though, TEL seems to be limited to the developed world, but its presence in countries like India and Brazil and schools for the rich in Nigeria exposes teachers to new digital teaching approaches thus producing a whole new generation of problem solving pupils who think and create and not just sit in classrooms waiting to be told what they should do and know. This is however, creating a knowledge and skill gap between children of the rich and the less privileged in the society, thus the need for government to make access to TEL equitable across all social strata in the society.

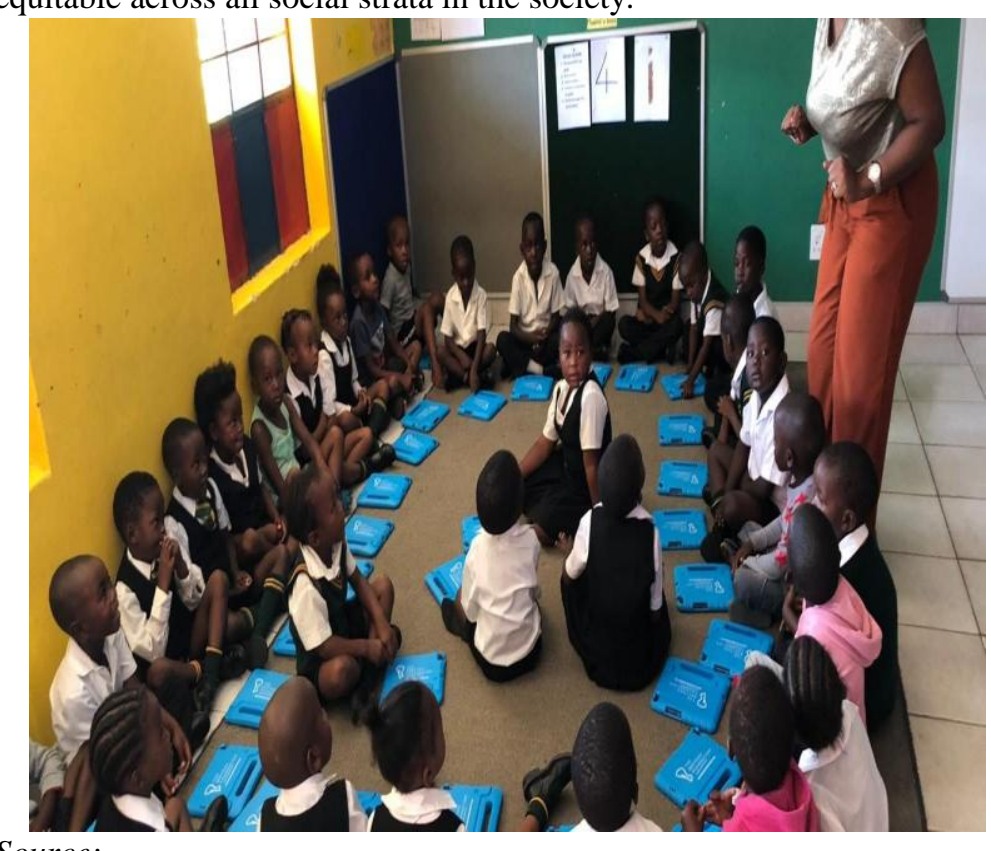

Source:

https://breteaufoundation.org/technology-inspires-great-ped agogy/

Figure 2: The use of Ipads in an interactive way

Appropriate TELs offer children with an equitable access to appropriate digital tools such as the use of tablets and tech to enhance their learning, and television especially for children in nursery in small doses. TEL facilitates learning with visualizing and modelling tools and ensures the transfer of requisite technological skill through experimentation. This method of curriculum delivery inspires learning through projects where pupils are intellectually challenged and stay more engaged on their tasks. For example, a primary four child who learns about the human heart or digestive system by way of 3D graphics and videos in a classroom equipped with a smart board would certainly have a faster grasp of the topic more than their counterparts in a chalkboard classroom. Thus, deploying TELs should be a project that is two-edged in which pupils are given tablets loaded with textbooks and their schools receive interactive whiteboards on the one hand and adapting curricula or teaching methods to a digital platform with teachers adequately trained on how to use tablets and smart whiteboard and related devices properly and 
Technology Enhanced Learning in Teaching Foundation Skills for Literacy and Numeracy among Vulnerable Children in the North Eastern Parts of Adamawa State

in a way that encourages learning.

\section{Pedagogical affordance and Sustainability of TEL}

Effective deployment of TEL means replacing chalkboards with smart boards, using projectors, digital libraries, smart devices, full time internet access and training of teachers to be technological compliant. At the centre of the advocacy for the deployment TEL across schools in Adamawa and Nigeria at large is the issue of affordability. Again, as earlier mentioned it borders on procurement cost and training cost. Going by what is obtainable in the market today, the following cost per device is presented:

Table 1: Market Prices of some TEL devices

\begin{tabular}{|r|l|l|c|c|}
\hline S/N & Device Name & Image & Unit Cost \$ & Unit Cost N \\
\hline 1 & $\begin{array}{l}\text { SMART } \\
\text { (molyboard) }\end{array}$ & & $100-300$ & $38,000-114,000$ \\
\hline 2 & Electronic Whiteboard & & $1000-650$ & $380,000-2,500,0$ \\
& & & 00 \\
\hline 3 & Projectors & & $65-120$ & $25000-46,000$ \\
\hline 4 & Educational Ipads/tablets & & $6.6-27$ & $2500-10,000$ \\
\hline 5 & Desktops and Laptops & & 19 & 7000 \\
\hline 6 & Television & & $40-270$ & $15000-100000$ \\
\hline
\end{tabular}

\section{Source: Online market survey, 2019}

Table 1 shows the current price ranges of some of the Technologically Enhanced Learning devices suitable for deployment in primary schools across the state. The prices range between 2500 to 2,500,000 per unit depending on the type. For instance, the molyboard suitable for pre-schoolers, nursery and primary 1-2 ranges between 38,000 to 114,000 naira; educational tablets and ipads that is supposed to be "one child-one tablet" has range between 2500 and 10,000 per unit; children's toy laptops cost 7,000 naira per unit and television range from 15,000 to 100,000 naira per unit. It would have been affordable in any case but for the current dollar to naira exchange rate. However, considering the profound effect, a tablet device of $\mathrm{N} 2,500$ could have on a child's learning experiences which through the power of technology result in a higher rate of absorption in the classroom than the actual impact of a teacher relying on traditional teaching methods is what makes the adoption and deployment of TEL attractive despite the cost. Furthermore, the cost of training teachers on the use of these new technologies for better learning outcomes, which ordinarily is supposed to be periodic, should not be a reason against the procurement and deployment of TEL in primary schools across the state.

From the assessment of pedagogical affordance, brings the question of sustainability of such technologies in Adamawa State. This we would posit depends on the will to move the less privilege to compete favourably in a technologically driven world. With adequate planning and systematic deployment of technologies, it is realisable and could be sustained. Hypothetically, if a government starts with the cheapest of tablets at 2,500 for a target 500,000 children would cost a total of 1.5 billion naira. If for every classroom, a simple projector and a screen worth 50,000 is procured for say 3000 classrooms, will amount to 250 million naira. Add to it the cost alternative electricity for use of the devices once a week at 5000per week by 12 days will amount to 60,000 per term, add to it the cost of training of teachers on how to use TEL in teaching and learning at all levels puts an estimate of about 3 billion naira. This would require a declaration of a state of emergency on education by a state government such as Adamawa for it to materialise and be sustained. However, if the government engages the Northeast Commission, the private sector and international organizations such as the UNICEF and USAID and other development partners, such a venture could come in the form of an aid and facilitate the sustainability of such a project in Adamawa State.

The level of adoption and domestication of TEL in Adamawa State

It is with respect to the identified technologies in the forms of devices tailored towards enhancing learning of the child that served as basis for assessing the level of adoption and domestication of TEL in basic education sphere in Adamawa State, especially with respect to the less privilege at IDP centers, Almajiri schools and public primary schools in the study area.

Table 2: Adoption and use of TEL in IDP Camps and Public Schools in Adamawa

\begin{tabular}{|c|l|l|l|l|l|l|l|l|l|l|}
\hline S/N & TEL DEVICES & MALKOHI & $\begin{array}{l}\text { CAPITAL } \\
\text { PRIMARY } \\
\text { SCHOOL }\end{array}$ & GOMBI & M/C & MPS & MCH & HNG & MDG & MAIH \\
\hline 1 & $\begin{array}{l}\text { Electronic } \\
\text { Whiteboards }\end{array}$ & - & - & - & - & - & & - & - & - \\
\hline 2 & Flipped Learning & + & - & - & - & - & - & - & - & - \\
\hline 3 & Desktops/Laptop & - & + & - & - & - & - & - & - & - \\
\hline 4 & S Projectors & - & - & - & - & - & - & - & - & - \\
\hline 5 & Mobile Learning & - & - & - & - & - & - & - & - & - \\
\hline
\end{tabular}




\begin{tabular}{|c|c|c|c|c|c|c|c|c|c|c|}
\hline 6 & Television/Radio & + & + & - & - & - & - & - & - & - \\
\hline 7 & IPADS/TOYS & - & - & - & - & - & - & - & - & - \\
\hline 8 & $\begin{array}{l}\text { Whiteboard/mark } \\
\text { er }\end{array}$ & - & - & - & - & - & - & - & - & - \\
\hline 9 & Blackboard/chalk & + & + & + & + & + & + & + & + & + \\
\hline
\end{tabular}

Field Survey, 2019

Table 1 shows that Adamawa state is still left behind when it comes to adoption of TEL in primary schools across all IDP camps and public primary schools. The table further revealed that besides the usual television and radio educational programs aired by media outfits such as Radio/TV Gotel, NTA, ATV, FRCN and ABC, no other modern technology is deployed. The television/radio programs are only accessible to few with access to radio/television. This is because most of the less privilege children are kept busy with household chores or selling of petty snacks to aid family income and so have no access to these media. Those in rural areas affected by insurgency are in a worst case scenario with access to any of the technologies but the old ones of the chalkboards and exercise books. Only capital school which is a model school in Jimeta, the commercial capital of Yola is equipped with desktop computers to which the pupils have limited access. In a nutshell, this study found that Adamawa is yet to join the league of those deploying TEL in primary schools across the state. The state has no single almajiri school system introduced in 2013 across northern states to give education to the almajiris in the north.

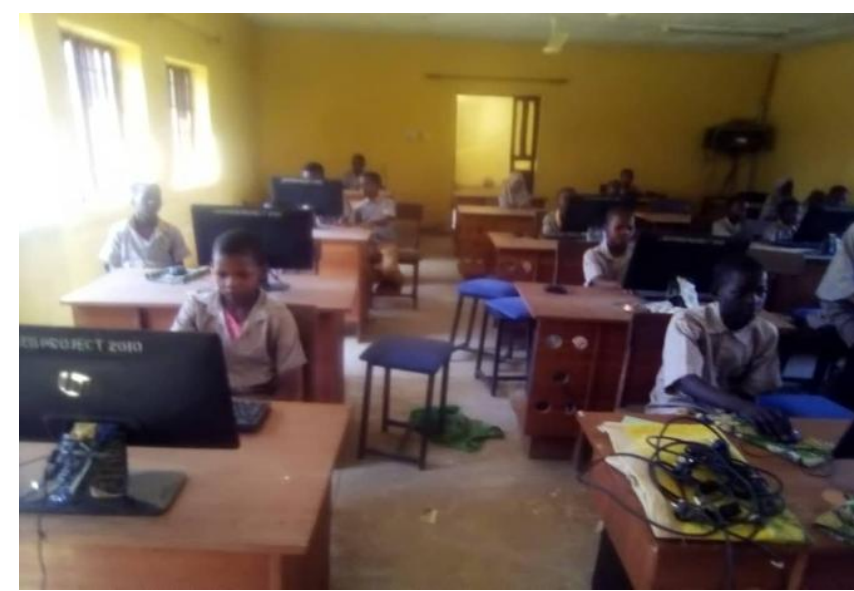

Figure 3: Atypical classroom with computer at Capital Primary School Yola

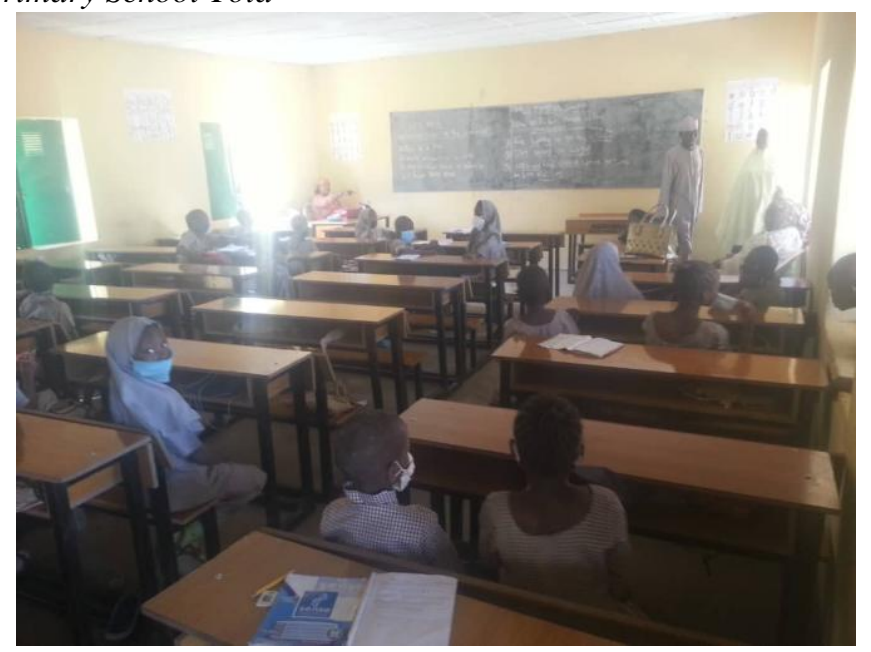

Figure 4: A typical classroom situation at Malkohi IDP camp

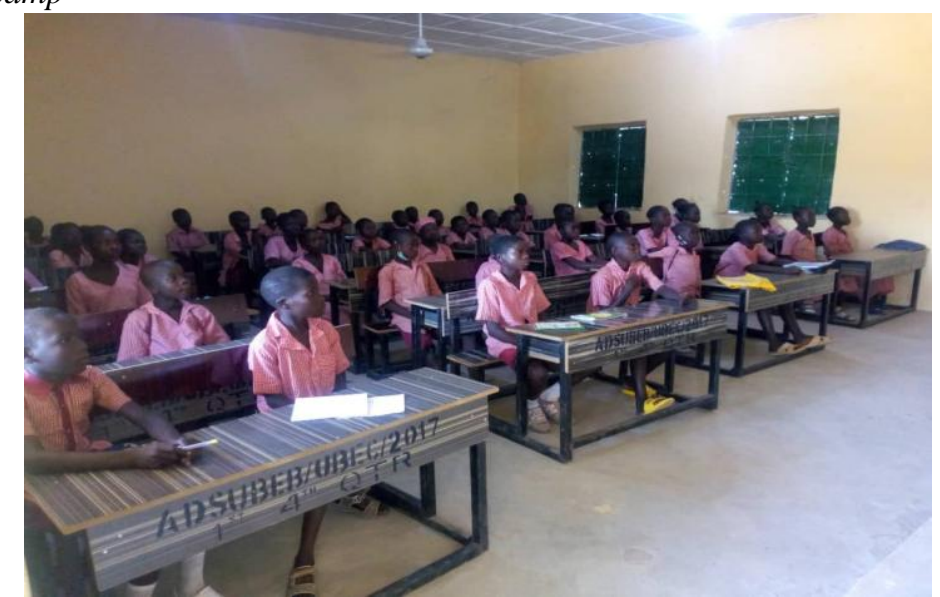

Figure 5: A typical classroom stiutation at Mubi central primary school

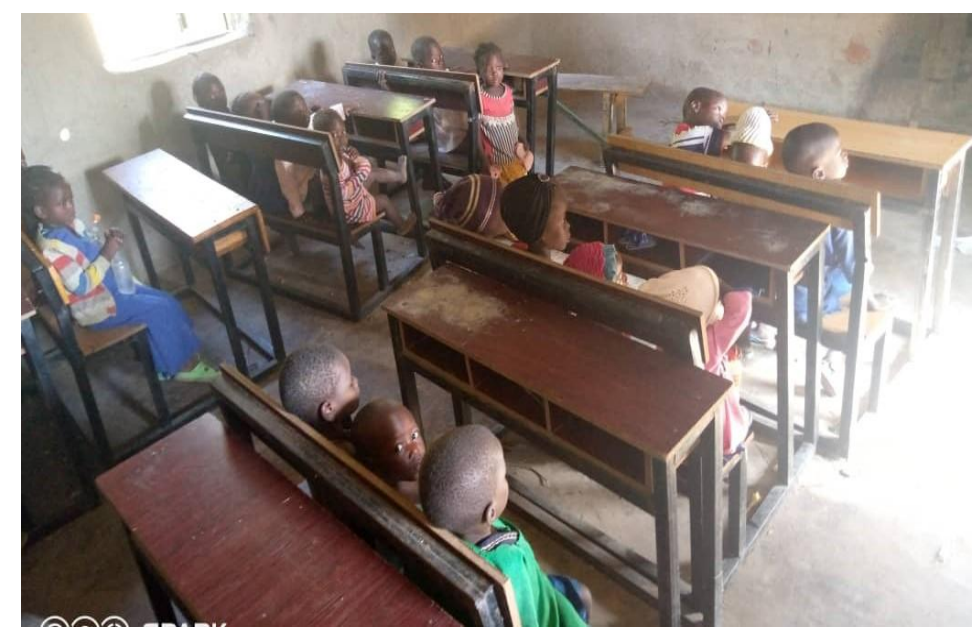

Figure 6: A typical classroom situation at Michika 1 Primary School

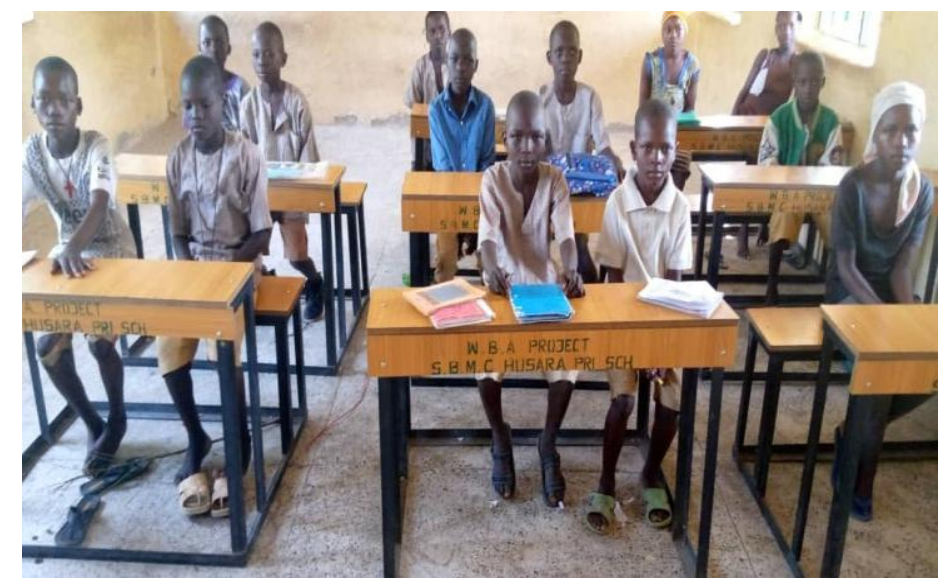

Figure 7: A typical classroom situation at Husara Primary School, Uba. 


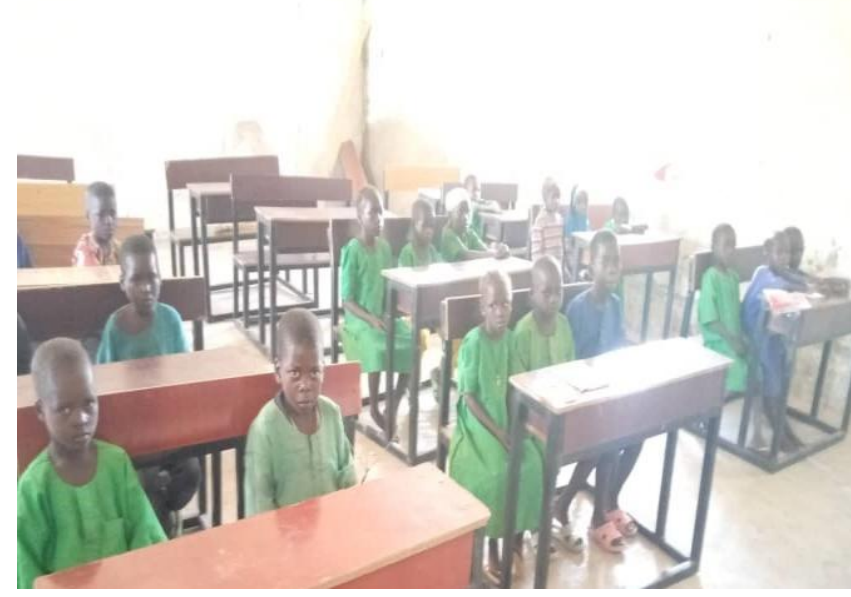

Figure 8: A typical classroom situation at Madagali Primary School

For most schools, technology integration means teaching students basic computer skills. In fact, several schools especially in rural areas remain generally under resourced in terms of TEL infrastructure. More with the fact that schools at the primary level falls under the jurisdiction of local education authorities and get paid from primary education boards that is not answerable to the local government administration leads to intermittency of salaries. This has over the years dampened the morale of primary educators. Unless this is addressed, the advancement of primary education through the deployment of TEL remains a mirage.

The teachers themselves lack the proficiency to deliver a technology driven curriculum. Some for lack of will power and cognition are at par with these technologies. Unless they are adequately trained and their teacher self-concept develops, it could affect the success of integrating TEL in primary school teaching infrastructure.

The TEL devices such as computers, smart devices and software remain prohibitively high for most schools. In rural Adamawa especially parts ravaged by insurgency, no parent can afford to buy devices for their children unless offered freely by the government.

Unless the content of this devices are tailored towards capturing the educational content of the Nigerian curriculum, the only knowledge that may be transferred is the skill of use of such technologies absent education that matters at the primary level.

Unless local manufacturers such as zinox computers are engaged, the cost of procurement and deployment will remain unaffordable. It is when such devices are affordable to the common man in rural Adamawa that the sustainability of deploying TEL will be sustainable. In this case, the technology must be domesticated.

Despite these technologies becoming more affordable by the day, the current set up in most African schools as observed by Ashaba (2015) does not guarantee their benefits to children, making the task of preparing them for tomorrow's competitive jobs an enormous one.

The success of the deployment of TEL cannot be instant but would require the implementation of a government driven purposeful agenda, supported by multilateral organizations and international aid agencies to equip schools with the right technology with a view to affording every child equitable opportunity to realizing their full potential and succeed in and outside of the classroom.

\section{CONCLUSION}

This research revealed that the north East, Adamawa in particular is lagging behind in terms of adoption of TEL across IDP camps and public primary schools as there are no other modern technology deployed in teaching and learning apart from the various media outfits in the state. A visit to the various schools indicated that chalk and white board markers including exercise books are the only materials available for teaching and learning. There are no proficiency for technology driven curriculum and besides that, most schools cannot afford devices like laptops and computers, projectors, mobile learning devices, television/radio, Ipad/itoys etc to settle in traditional ways. It must continue its transformation with the support of technology in every facet of our lives. In this regards, technology-enhanced learning environments does not only promote the transfer of content but also support the use of strong e-assessment methods and in a bid to collaborate and compete with the world, education must be a prime factor that is based on global perspective. Job opportunities in today's world are based on higher levels of thinking capabilities and skills which inadvertently becomes almost impossible without the use of technology.

Parents both literate and illiterate want their children to graduate with skills that will prepare them for a better future, while employers prefer employees who are reliably intelligent, literate, communicate better and make accurate decision in today's corporate world. Hence the need to essentially develop and enhance their skills through technological learning from primary to tertiary levels of education as this will help them with real-life association and the ability to work in cross-functional environments.

Technology allows students to see the whole world as a resource with themselves being in charge of their destiny. It also benefits students because they have choices and opportunities to explore and share information to a greater extent than available in a traditional classroom. Schools can use technology enhanced learning effectively and for the welfare of students, teachers and the society which makes the world a global village.

\section{RECOMMENDATIONS}

Based on the outcome of this research, the following recommendations have been proffered:

i. Government should as a matter of urgency provide appropriate equipment and materials needed for effective TEL programs in all the Federating units.

ii. All early childhood education and child care programs should have access to qualified in related field of ICT

iii. Both federal and state ministries of education, human resources and agencies interested in children 
education should initiate programs aimed at promoting TEL activities

iv. Non-governmental organizations should be encouraged to promote ICT driven curriculum in addition to their humanitarian activities

v. Proper curricula which must be in line with current technological realities must be adopted

vi. Monitoring, evaluation and implementation of childhood programs must be strictly supervised in all institutions of learning.

\section{REFERENCES}

[1] African Union Convention for the Protection and Assistance of Internally Displaced Persons in Africa, (Kampala Convention).Adopted by the Special Summit of the Union held in Kampala on 22 October 2009.

[2] Beetham, H. (2007). An approach to learning activity design. In H. Beetham \& R. Sharpe (Eds.)Rethinking pedagogy for a digital age. London and New York: Routledge.

[3] Beetham, H., \& Sharpe, R. (Eds.) (2007).Rethinking pedagogy for a digital age. London and New York: Routledge.

[4] Center for Children and Technology (2004).Television Goes to School: The Impact of Video on Student Learning in Formal Education (PDF). New York, NY:

[5] Conole G and Oliver M 1997 A Pedagogical Framework for Embedding C\&IT into the Curriculum, ALT-Journal 6 (2): 4-16.

[6] De Freitas, S., \& Oliver, M. (2005) Does E-Learning policy drive change in Higher Education? A Case Study Relating Models of Organizational Change to e- Learning Implementation. Higher Education Policy \& Management, 27 (1), 81- 95.

[7] Education, 127(4), 462-471. Retrieved from Ebscohost database.

[8] Falconer L. (2011).Technology Enhanced Learning at UWE 2011 Results of a teaching staff survey in 2011 and comparison with the 2009 survey. Education Innovation Centre, August2011.Availableat http://www.uwe.ac.uk/elearning/intranet/publications/Technology En hanced Learning_at_UWE_2011.pdf

[9] Internally Displaced Persons in Nigeria, www.news24.com.ng/National/News/laws-to-protectrights-of-idps-will-soon-beenacted- dogara-20160223 last assessed 23rd Feb. 2016.

[10] Marshall S. (2010). Change, technology and higher education: are universities capable of organizational change? ALT-J, 18, (3), pp. 179-192. Begin to move towards this from September 2012 Substantially achieved by July 2013.

[11] Perraton, H. D. (2000). Open and distance learning in the developing world. London: RoutledgeFalmer.

[12] Perraton, H., Robinson, B. and Creed, C. 2007 (ed.) International case studies of teacher education at a distance, Oldenburg: BIS-Verla

[13] Sharpe, R. (2004). A typology of effective interventions that support e-learning practice, JISC e- learning programme report, retrieved December 16, 2006, from http://www.cetis.ac.uk:8080/pedagogy/research_study/

[14] STELLAR net Concept and Project Objectives. http://www.stellarnet.eu/about/ 2013.

[15] Stuart J.S. \& Lewin K.M. (2002) 'Editorial Foreword' in Researching Teacher Education: The Multi-Site Teacher Education Project Special Issue of the International Journal of Educational Development $22(3 / 4)$.

[16] Stuart J.S. \& Tatto M.T. (2000) 'Designs for Initial Teacher Preparation Programmes: An International View'. International Journal of Educational Research, 33 (5)

[17] UNESCO 2010 EFA global monitoring report: Reaching the marginalized, Oxford: Oxford University Press

[18] Walker, A. (1997). Introduction: The Strategy of Inequality. In A. Walker and C Walker (eds.), Britain divided: the growth of social exclusion in the 1980s and 1990s. London: Child Poverty Action Group.

[19] World Bank (1978) Teacher Training and Student Achievement in Less Developed Countries. World Bank Staff Working Paper No 310, World Bank, Washington. 